\title{
Occurrence of an abnormal lipoprotein in patients with liver disease
}

\author{
A. ROSS, G. M. MURPHY, P. A. WILKINSON, G. L. Mills, AND \\ S. SHERLOCK \\ From the Department of Medicine, Royal Free Hospital, and the \\ Courtauld Institute of Biochemistry, Middlesex Hospital Medical School, London
}

SUMMARY An abnormal lipoprotein, containing a high proportion of unesterified cholesterol and phospholipid, has previously been described as occurring in the serum of patients with obstructive jaundice, and has been called lipoprotein $X$. Using an immunoelectrophoretic method for the detection of lipoprotein $X$ in serum, the sera of 97 patients with liver disease have been screened and the associated biochemical features measured.

Lipoprotein $\mathrm{X}$ was found in $45 \%$ of cases of liver disease with cholestatic features, and was not detected in cases of liver disease without cholestasis. The incidence of lipoprotein $\mathrm{X}$ in different causes of cholestatis varied, and while it was commonest in cases of extrahepatic obstruction of recent onset, occurring in $75 \%$ of cases, it was also found in primary biliary cirrhosis in $48 \%$ of cases, and in cholestatic hepatitis, less commonly.

The cause of the appearance of lipoprotein $X$ is unknown, but analysis of associated biochemical features suggested a relationship to physical biliary obstruction rather than a derangement of liver cell function.

Patients with liver disease with obstructive features are known to have raised levels of serum lipids, and a hyperlipoproteinaemia has been demonstrated by many investigators (Kunkel and Ahrens, 1949; Kunkel and Slater, 1952; Eder, Russ, Pritchett, Wilber, and Barr, 1955). Ultracentrifugation of the lipoproteins has shown that there is an increase in the low density lipoprotein fraction and a decrease in the high density lipoprotein fraction (Furman and Conrad, 1957). It was then demonstrated, using antiserum against normal serum lipoproteins, that there was a lipoprotein present which failed to react (Russ, Raymunt, and Barr, 1956; Switzer, 1967). This lipoprotein was isolated and shown to contain a high proportion of unesterified cholesterol and phospholipid (Switzer, 1967). Analysis of the serum of patients with obstructive jaundice by ultracentrifugation and an immunological technique has demonstrated that there is an abnormal lipoprotein present in the LDL fraction, and that it has a similar chemical composition to the Received for publication 1 September 1970. previously described lipoprotein (Seidel, Alaupovic, and Furman, 1969). This lipoprotein has been called lipoprotein $X$.

In a study of 67 patients with jaundice, it has been reported that lipoprotein $X$ could be detected only in the serum of patients in whom primary obstruction was a feature (Seidel et al,1969). These patients included 24 with extrahepatic biliary obstruction and 10 with biliary cirrhosis. Lipoprotein $\mathrm{X}$ was also demonstrated in three out of 13 patients with Laennec's cirrhosis. It was not detected in patients with viral hepatitis. On the basis of these results, it was suggested that screening for the presence of lipoprotein $X$ might be useful in the differential diagnosis of obstructive and nonobstructive jaundice.

In the clinical situation, difficulty arises in the distinction of jaundice due to obstruction of the extrahepatic ducts and jaundice due to intrahepatic disease; both these groups may present with a cholestatic picture of obstruction to biliary flow. A variety of diseases may cause intrahepatic cholestasis, and these include drug 
sensitivity reactions, viral hepatitis, primary biliary cirrhosis, and some cases of cryptogenic cirrhosis (Sherlock, 1968).

In order to assess the incidence of lipoprotein $X$ in these diseases, and the value of screening for its presence in their diagnosis, a survey of patients with liver disease with cholestatic features was carried out. Biochemical indices of liver function were estimated to try to relate the presence of lipoprotein $\mathrm{X}$ to any particular aspect of liver function, as it has been suggested that lipoprotein $\mathrm{X}$ may accumulate because of a failure of catabolism due to liver failure or to the inhibition of metabolic pathways by high bile salt concentrations (Seidel et al, 1969).

\section{Patients Studied}

Ninety-seven patients with liver disease were studied; 67 of these patients had cholestatic features, as judged clinically by the presence of pruritus and biochemically by a high alkaline phosphatase. In this group were included 17 patients with large duct obstruction, 33 patients with primary biliary cirrhosis. Twelve patients with cholestatic hepatitis due to viral hepatitis or drugs, and five patients with cryptogenic cirrhosis. The 30 patients with non-cholestatic liver disease included patients with alcoholic cirrhosis, active chronic hepatitis, and viral hepatitis; three patients were in terminal liver failure. Thirty normal sera were also tested.

\section{Methods}

Lipoprotein $\mathrm{X}$ was screened for by an immunoelectrophoretic technique, as described by Seidel

\begin{tabular}{lll}
\hline Diagnosis & No. Tested & Lipoprotein X Present \\
\hline Non-cholestatic liver disease & 30 & - \\
Cholestatic liver disease & 67 & $30(45 \%)$ \\
Large duct obstruction & 17 & $11(65 \%)$ \\
Primary biliary cirrhosis & 33 & $16(48 \%)$ \\
Cholestatic hepatitis & 12 & $3(25 \%)$ \\
Cholestatic cirrhosis & 5 & $3(60 \%)$
\end{tabular}

Table I Incidence of lipoprotein $X$ in different diseases of the liver

\begin{tabular}{|c|c|c|c|c|c|}
\hline $\begin{array}{l}\text { Large Duct } \\
\text { Obstruction }\end{array}$ & $\begin{array}{l}\text { No. of } \\
\text { Patients }\end{array}$ & $\begin{array}{l}\text { Lipoprotein } X \\
\text { Present }\end{array}$ & $\begin{array}{l}\text { Bilirubin } \\
( \pm 1 S D)\end{array}$ & $\begin{array}{l}\text { Alkaline } \\
\text { Phosphatase } \\
( \pm I S D)\end{array}$ & $\begin{array}{l}\text { Cholesterol } \\
( \pm I S D)\end{array}$ \\
\hline \multirow{2}{*}{$\begin{array}{l}\text { Group } A \\
<3 \text { months } \\
\text { Group } B \\
>3 \text { months }\end{array}$} & 8 & $6(75 \%)$ & $16 \cdot 1 \pm 10 \cdot 7$ & $93 \cdot 8 \pm 54 \cdot 5$ & $328.4 \pm 228 \cdot 4$ \\
\hline & 9 & $5(56 \%)$ & $8 \cdot 1 \pm 6 \cdot 7$ & $99 \cdot 8 \pm 53 \cdot 5$ & $303.9 \pm 97.0$ \\
\hline
\end{tabular}

Table II Incidence of lipoprotein $X$ and biochemical findings in large duct obstruction according to the duration of obstruction et al (1969). Specific antiserum to lipoprotein $X$ was raised in rabbits, immunized with the lipoprotein $\mathrm{X}$ fraction isolated from human obstructive jaundice serum. Immunoelectrophoresis was performed in $1 \%$ agar gel; a singleo precipitin line was seen in a characteristic position $\overline{0}$ on the cathode side of the origin, in the presence $\frac{\bar{F}}{\bar{T}}$ of lipoprotein X. The result was recorded as $\stackrel{\Phi}{\varnothing}$ positive or negative.

Serum bilirubin, alkaline phosphatase, and total cholesterol were measured by a routine? AutoAnalyzer method. The normal values for $\overrightarrow{\vec{\omega}}$ these methods are: bilirubin less than $1 \mathrm{mg} / 100 \mathrm{ml}$, $\stackrel{\sim}{\omega}$ alkaline phosphatase $3-13 \mathrm{KA}$ units $/ 100 \mathrm{ml}$, and total cholesterol $130-260 \mathrm{mg} / 100 \mathrm{ml}$.

Serum total bile salts were measured in 31 cases. by an enzymatic method (Murphy, Billing, and $\vec{N}$ Baron, 1970). The normal range for this method is $\vec{O}$ 0-5 $\mu \mathrm{mol} /$ litre.

Needle biopsy of the liver was performed, in 을 most cases, to confirm the clinical diagnosis.

\section{Results}

Lipoprotein $X$ was detected in $45 \%$ of the $67 \vec{\vartheta}$ cases of liver disease with cholestasis, but was not detected in any of the 30 cases of liver disease without cholestasis; this difference was highly significant $(P<0.01)$.

All the normal sera were also negative for lipoprotein $\mathrm{X}$.

The incidence of lipoprotein $\mathrm{X}$ in different liver $\overrightarrow{\vec{P}}$ diseases is shown in Table I. Sixty-five per cent of $\frac{0}{3}$ the 17 cases of large duct obstruction were posi- $\overline{ }$ tive for the lipoprotein, as were $48 \%$ of 33 cases of primary biliary cirrhosis. The incidence of a

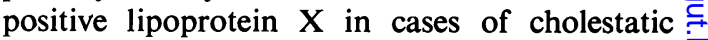
hepatitis was lower, $25 \%$ of 12 cases; this was $\frac{5}{3}$ significantly different from the incidence in large duct obstruction $(P<0.05)$, but not significantly $\frac{\circ}{3}$ different from the incidence in primary biliary cirrhosis. Three out of five cases of cryptogenic $\frac{9}{5}$ cirrhosis with cholestatic features were positive for lipoprotein $\mathrm{X}$.

The cases of large duct obstruction were further $N$ subdivided according to the duration of obstruc- $N$ tion, as shown in Table II. Eight cases had been $\mathrm{N}$ obstructed for.less than three months at the time of $\omega$ testing and of these, six were positive for lipoprotein X. These cases form group $\mathrm{A}$; of the remaining nine patients obstructed for more than three months (group B), five patients were? positive for the lipoprotein. This difference was not statistically significant.

The results of biochemical tests are shown in Table III, and are grouped according to the $\varrho$ presence or absence of lipoprotein X. In patients with primary biliary cirrhosis, the serum bili- o rubin, alkaline phosphatase, cholesterol, and bile salt levels were all significantly higher in those in whom lipoprotein was present than in 


\begin{tabular}{|c|c|c|c|c|c|}
\hline & Lipoprotein $X$ & $\begin{array}{l}\text { Bilirubin } \\
( \pm 1 S D)\end{array}$ & $\begin{array}{l}\text { Alkaline Phosphatase } \\
( \pm 1 S D)\end{array}$ & $\begin{array}{l}\text { Cholesterol } \\
( \pm 1 S D)\end{array}$ & $\begin{array}{l}\text { Bile Salts } \\
( \pm 1 S D)\end{array}$ \\
\hline Primary biliary cirrhosis & \pm & $\begin{array}{c}11 \cdot 3 \pm 6 \cdot 6^{1} \\
2 \cdot 0+2 \cdot 0\end{array}$ & $\begin{array}{l}91 \cdot 4 \pm 32 \cdot 4^{2} \\
64 \cdot 3+32 \cdot 3\end{array}$ & $\begin{array}{l}393 \cdot 4 \pm 161 \cdot 0^{2} \\
276 \cdot 3 \pm 78 \cdot 1\end{array}$ & $\begin{array}{c}161 \cdot 3 \pm 67 \cdot 8 \\
64 \cdot 8+51 \cdot 0\end{array}$ \\
\hline Large duct obstruction & + & $13 \cdot 7 \pm 10 \cdot 2$ & $116.9 \pm 50 \cdot 3^{1}$ & $\begin{array}{l}276 \cdot 3 \pm 78 \cdot 1 \\
364 \cdot 3 \pm 66 \cdot 1^{2}\end{array}$ & $\begin{array}{r}64 \cdot 8 \pm 51 \cdot 0 \\
113 \cdot 5 \pm 62 \cdot 6\end{array}$ \\
\hline Cholestatic hepatitis & $\overline{\text { All cases }}$ & $\begin{array}{r}8.2 \pm 6.9 \\
13 \cdot 6 \pm 9 \cdot 4\end{array}$ & $\begin{array}{l}49 \cdot 3 \pm 31 \cdot 3 \\
45 \cdot 7 \pm 36 \cdot 7\end{array}$ & $\begin{array}{l}209 \cdot 0 \pm 190 \cdot 0 \\
321 \cdot 7 \pm 228 \cdot 5\end{array}$ & $109 \cdot 8 \pm 61.5$ \\
\hline Cholestatic cirrhosis & All cases & $7 \cdot 0 \pm 6 \cdot 6$ & $76.8 \pm 18.9$ & $\begin{array}{l}321 \cdot 7 \pm 228 \cdot 3 \\
240 \cdot 0 \pm 51 \cdot 0\end{array}$ & - \\
\hline
\end{tabular}

Table III Biochemical findings in cholestatic liver disease with and without lipoprotein $X$ present

${ }^{1}$ Significance levels (Student's t test) $P<0.01$.

${ }^{2}$ Significance levels (Student's $t$ test) $P<0.05$.

\begin{tabular}{|c|c|c|c|c|c|c|}
\hline Case & $\begin{array}{l}\text { Days after } \\
\text { Operation }\end{array}$ & Lipoprotein $X$ & Bilirubin & $\begin{array}{l}\text { Alkaline } \\
\text { Phosphatase }\end{array}$ & $e^{\text {Cholesterol }}$ & Bile Salts \\
\hline 1 & $\begin{array}{l}0 \\
7\end{array}$ & \pm & $\begin{array}{r}28.0 \\
6.5\end{array}$ & $\begin{array}{r}180 \\
30\end{array}$ & $\begin{array}{l}250 \\
200\end{array}$ & $\begin{array}{r}115 \\
84\end{array}$ \\
\hline 2 & $\begin{array}{r}0 \\
7 \\
14\end{array}$ & $\begin{array}{l}+ \\
+ \\
-\end{array}$ & $\begin{array}{c}21 \\
10 \\
7 \cdot 9\end{array}$ & $\begin{array}{r}200 \\
52 \\
45\end{array}$ & $\begin{array}{l}340 \\
130 \\
120\end{array}$ & $\begin{array}{l}185 \\
160 \\
137\end{array}$ \\
\hline 3 & $\begin{array}{r}0 \\
10\end{array}$ & \pm & $\begin{array}{r}8 \cdot 5 \\
15.5\end{array}$ & $\begin{array}{l}70 \\
32\end{array}$ & $\begin{array}{l}240 \\
165\end{array}$ & $\begin{array}{l}87 \\
61\end{array}$ \\
\hline 4 & $\begin{array}{r}0 \\
14\end{array}$ & \pm & $\begin{array}{l}6 \cdot 5 \\
2 \cdot 4\end{array}$ & $\begin{array}{l}80 \\
64\end{array}$ & $\begin{array}{l}315 \\
152\end{array}$ & $\begin{array}{r}102 \\
69\end{array}$ \\
\hline 5 & $\begin{array}{r}0 \\
14\end{array}$ & \pm & $\begin{array}{l}20 \\
11 \cdot 6\end{array}$ & $\begin{array}{l}84 \\
34\end{array}$ & $\begin{array}{r}1,000 \\
350\end{array}$ & $\begin{array}{r}182 \\
97\end{array}$ \\
\hline
\end{tabular}

Table IV Biochemistry and lipoprotein $X$ in cases of large duct obstruction before and after surgery

those in whom it was absent. In the cases of large duct obstruction, only the alkaline phosphatase and cholesterol were significantly higher when lipoprotein $\mathrm{X}$ was present. The mean bile salt levels did not differ significantly.

The results of biochemical studies in the patients with cholestatic hepatitis and cryptogenic cirrhosis are also shown in Table III, but these results are not subdivided, as the numbers are small.

Five patients with large duct obstruction and positive lipoprotein $\mathrm{X}$ were followed after successful relief of obstruction by surgery. In all the cases, the lipoprotein had disappeared within two weeks of operation and diminishing precipitin lines were seen during this time. Table IV shows the preoperative and postoperative results in these cases.

\section{Discussion}

These results confirm that lipoprotein $\mathrm{X}$ is found only in the serum of patients with liver disease and cholestatic features. The incidence of positive results varies with different causes of cholestasis, but in no disease was it always present. While the highest incidence was in cases of recent large duct obstruction, this is not of diagnostic significance, as lipoprotein $\mathrm{X}$ was also found in intrahepatic causes of cholestasis. As the technique used is not quantitative the lower limit for detection of the lipoprotein is not known.
The origin of lipoprotein $\mathrm{X}$ is unknown; it has been suggested that it may be an intestinal lipoprotein, normally catabolized in the liver, and accumulating as a result of liver dysfunction. However, in this study lipoprotein $\mathrm{X}$ was not detected in cases of terminal liver failure. The possibility of bile salt inhibition of catabolic reactions has also been suggested as an explanation, but the finding of similar bile salt concentrations in large duct obstruction, whether or not the lipoprotein was present, does not support this theory.

Study of the biochemical results suggests that physical obstruction to bile flow may be of importance in the pathogenesis of lipoprotein X. In the cases of large duct obstruction, the most significant biochemical feature was a high alkaline phosphatase, which may reflect the degree of biliary obstruction. In the cases of primary biliary cirrhosis, a raised serum bilirubin level was most significantly associated with the presence of lipoprotein $X$, and this measurement reflects the stage of the disease, rising as biliary fibrosis progresses. After relief of biliary obstruction, lipoprotein $\mathrm{X}$ disappeared within two weeks.

\section{References}

Eder, H. A., Russ, E. M., Pritchett, R. A. R., Wilber, M. M., and Barr, D. P. (1955). Protein-lipid relationships in human plasma: in biliary cirrhosis, obstructive jaundice and acute hepatitis. J. clin. Invest., 34, 1147-1162.

Furman, R. H., and Conrad, L. L. (1957). Ultracentrifugal characterisation of the lipoprotein spectrum in obstructive jaundice: studies of serum lipid relationships in intra and extrahepatic biliary obstruction.J. clin. Invest., 36, 713-722.

Kunkel, H. G., and Ahrens, E. H. Jr. (1949). The relationship between serum lipids and the electrophoretic pattern, with particular reference to patients with primary biliary cirrhosis. J. clin. Invest., 28, 1575-1579.

Kunkel, H. G., and Slater, R. J. (1952). Lipoprotein pattern of serum obtained by zone electrophoresis. J. clin. Invest., 31 , 677-684.

Murphy, G. M., Billing, B. H., and Baron, D. N. (1970). A fluorimetric and enzymatic method for the estimation of serum total bile acids. J. clin. Path., 23, 594-598.

Russ, E. M., Raymunt, J., and Barr, D. P. (1956). Lipoproteins in primary biliary cirrhosis. J. clin. Invest., 35, 133-144.

Seidel, D., Alaupovic, P., and Furman, R. H. (1969). A lipoprotein characterising obstructive jaundice. I. Method for quantitative separation and identification of lipoproteins in jaundiced subjects. J. clin. Invest., 48, 1211-1223.

Sherlock, S. (1968). Chronic cholangitides: aetiology, diagnosis, and treatment. Brit. med. J., 3, 515-521.

Switzer, S. (1967). Plasma lipoproteins in liver disease. I. Immunologically distinct low-density lipoproteins in patients with biliary obstruction. J. clin. Invest., 46, 1855-1866. 